\title{
Brexit and the German Question Simon Glendinning
}

Consider three very intuitive thoughts. First, that the most decisive considerations for UK citizens who voted to leave the European Union were framed in terms of freedom - freedom as a political concept. If any slogan gave voice to the voice of Leavers it was "Take back control". Second, and not very distantly related, is an assumption bordering on plain fact that the European Union, however closely identified with the faceless bureaucracy of "Brussels", is dominated by Germany as a de-facto quasi-hegemonic power. And third, that France is caught up in all of this - caught up in it not least because it had initially blocked the UK becoming a member in the first place, and also because its principal motivation for pressing for the development of a transnational organization in Europe after the Second World War was to pacify Germany.

These are all recent geopolitical features of the European landscape, and concern the sort of things one might read about in an op-ed piece about what is going on in Europe today.

In Europe. It is such a familiar (if vague) territorial outline that it is hard sometimes to remember how bizarre it is that there should be any such outline at all. A little promontory on the western edge of a great landmass: it became "Europe".

How did it come to be there? Historians can be more or less one dimensional, more or less monogenealogical, but part of the business of the historian of Europe is to see how that territorial outline settled where it has (in so far as it has) by tracing the sequence of world-historical events which have brought it (and, for "we, the Europeans", us) where it (and this "we") are today. And, in the classic European discourse of Europe's history there really is only one sequence to follow. This (the only) history is: Greek-Roman-Christian-Modern. Nothing could be more European than this history of Europe.

Greek-Roman-Christian-Modern. But surely that (roughly) is the history of Europe. Right. Europe has produced itself, called itself to be, by making it so that this history will have been its history.

And yet this European history is not one. This history of Europe's becoming is also the history of its (becoming) nation-states. And these nation-states have each had their own relating of the classic sequence in relation to their own becoming, and have done so as ways of relating themselves to themselves, as in some way also European. In what follows I want to step back to a time in Europe's history when the Germanic peoples were, for the first time and relatively late in the day, configuring into a national shape. Philosophically this was the time of Nietzsche, and I will take a point of departure from him in order to rush forward again to our own time.

\section{II}

In Nietzsche's writings "Europe" comes to name an "unexhausted" promise of its own exhausted past. And this passage to its own "beyond" will make its way, he suggests, through the mechanism of a new hidden hand, a new cunning of reason that belongs within the tidal wave of what he calls "the democratic movement in Europe" that unfolds out of the French Revolution (Nietzsche: 1973, p. 153). It is into this wave that Nietzsche sends an untimely message-in-a-bottle, and a call to the future of a certain friendship of "we good Europeans". 
Why Europeans? Why the emphasis on "good Europeans"? In his insistent opposition to the growing nationalist appeal in Germany to "we good Germans", why wouldn't Nietzsche say, simply, "we good whoevers"? One might want to excuse Nietzsche by referring to the "context" of his times: the world was not so big then, the horizon for his thinking was European because his world was. But that is nonsense. Nietzsche's work is peppered with non-European references, and often, typically even, with great admiration. Nevertheless, while he asks "What Europe owes the Jews?" (Nietzsche: 1973, p. 161), he does not stop to ask "What Europe owes the non-European in general?", nor even just the non-European migrants into Europe. Nietzsche certainly thinks that the now exhausted Europe has been a site of "great things" (Nietzsche: 1973, p. 13) - but he does not think that Europe has a monopoly on that at all: Asia and Egypt are mentioned in the same breath. So why the limit to thinking the newly cosmopolitan "plant 'Man'" of the future to the indefinite but definitively European milieu? Is it white racism? Eurocentric parochialism? Modest pragmatism? My suspicion is that it is none of those. It is above all...German.

The German question ("What is Germany?") casts a profoundly determining shadow over Nietzsche's reflections on Europe. I will only track that a little here. However, it deserves something more ambitious, and my hypothesis would be that when Germany thinks itself it thinks itself in an essentially European horizon, a European horizon that it invents and projects as the context of its own "spiritual" destiny. Germany will not have been alone in this, nor even the first to do so. Indeed, as I have indicated, no European people has ever been able entirely to do otherwise: there is, we might say, an ongoing agon of mainly national projections internal to Europe's cultural identity.

Nevertheless, there is, I think, a peculiar intimacy between the German question and the European question, or at least a distinctive shaping of both in that relation. We know how difficult it is to comprehend how the horrors of National Socialism could possibly belong within German history except as an absolute aberration. But with the invitation to think Europe as a German thing, I do not mean this to imply that we must always be on our guard against what Jürgen Habermas has called a "fatal" temptation for Germany to "succumb to power fantasies" of achieving "'semi-hegemonic status" in Europe. (All references to Habermas here are to his online article, "Democracy, Solidarity and The European Crisis", https://www.socialeurope.eu/2013/05/democracy-solidarity-and-theeuropean-crisis/.) No, the European horizon is just as visible in Habermas's own call for Germany finally to give up those fantasies as some kind of repentance for its indulging them. Habermas may make a more welcome gesture when he says "that it is in our [German] national interest to permanently avoid" them, since not doing so leads only to "catastrophe". But it is still the same programme: German national interests and German destiny are conceived, I want to suggest, as inseparably connected to a particular European future. Not only that it will have one (I'll come back to that idea too) but that properly having one is critically bound up with the realisation, led by Germany, of a political union among its peoples. Habermas's call for rapid steps to be taken towards the formation of a "supranational democracy" at the European level, and the crossing of "the red line of the classical understanding of [national] sovereignty" that this would entail, is fully part of this German story, as is his insistence that "the German government holds the key to the fate of the European Union in its hand". These intertwined fates and fatalities belong, I think, to "the German question", making of it at once entangled with what Habermas calls "the European question".

"Europe" may be something of a German thing. But of course it is not only a German thing. Not only has it never long remained an uncontested German thing - other becoming-Europeans will have their own ideas - but as the French philosopher Phillipe Lacoue-Labarthe has stressed, the German way of styling "Europe as a whole" is something whose development was "essentially induced by the French one" (Lacoue-Labarthe: 2007, p. 79). There is a fascinating tête-à-tête between France and Germany here, what Lacoue-Labarthe calls "a mimetic rivalry" that is played out in relation to the question of "the imitation of the Ancients" (Lacoue-Labarth: 1990, p. 90). With both rivals conceiving 
Greek antiquity as the point of origin of a movement of world history which unfolds into Europe's modernity, Lacoue-Labarthe identifies two distinctive models of self-identification, French and German respectively, that are forged through the appropriation of that heritage, and through that the future of Europe. France, on the one hand, returns to Greece through "Latinity": the Roman and Renaissance imitation. The Germanic world, on the other hand, "situated beyond the limes" of Latinity, is faced with the choice, in Alfred Bäumler's words, "to be either the anti-Roman power of Europe or not to be" (Lacoue-Labarth: 1990, p. 91). Germany finds its voice in this struggle over the appropriation of the Greeks, aspiring to create itself thereby as the "the creator of a Europe that will be more than a Roman colony" - and to do so through the inheritance of "an altogether different Greece" (Lacoue-Labarthe: 1990, p. 91). This other imitation finds its decisive expression in Winckelmann's famous invocation to the Germans to imitate the Ancients "in order to make ourselves inimitable in turn". In this "Kulturkampf" with French neo-classicism and republicanism (Greek-Roman-Christian-revolutionary), it became necessary for Germany "to 'invent' a Greece which had up to that point remained unimitated... which would allegedly be at the foundation of Greece itself... What the German imitation is seeking in Greece is the model - and therefore the possibility - of a pure emergence, of a pure originality: a model of self-formation" (Lacoue-Labarthe: 2007, p. 79).

One might begin to summarise all of this by recalling the Delphic Oracle's reply to Zeno: "Take on the colour of the dead" - which Zeno interpreted as "study the ancients"; repeat them. And then we have two models: either the Latin model which is do what they did in the sense of becoming like them in your ways (democratic self-government), or the German model which is do what they did in the sense of becoming yourself in your own ways (autochthonous).

In his discussion of the German sword-in-the-tree called "Nothung" that cuts through Wagner's Ring cycle, Mulhall invites us to follow something of Nietzsche's claim to see "the Wagnerian representation of Wotan's overthrow....as itself the refounding of a new, non-Christian [ie. non-Latin, SG] culture that might run counter to the philistinism of contemporary Germany by reconnecting Europe to its sources in Greek culture" (Mulhall: 2013, p. 22, my emphasis). Mulhall speaks here about Germany/Europe and its genealogy not in geopolitical terms but geophilosophical terms: through its Greek philosophical origin. Germany, attaining itself in this appropriative way - through the authentic repetition of the inimitable rather than the mere imitation of the classics - would enable Europe too to attain to "the innermost course of its history" which, as Heidegger will insist, was "originally 'philosophical'" (Heidegger: 1956, p. 31). Nietzsche came to think that "late Wagner" lost his way and began to "preach the road to Rome" in his Parsifal (Nietzsche: 1973, pp. 171-2). "Is this still German?" asks Nietzsche pointedly, and with barely disguised disgust, in a rhyme that closes the "Peoples and Fatherlands" chapter of Beyond Good and Evil. In the Querelle des Anciens et des Modernes played out in this Franco-German duet it barely makes a difference whether the German "key" is sounded through an affirmation of the Germanization of Europe (though a union that would overturn Latinity) or the Europeanization of Germany (through the authentic repetition of the originary, non-Latin, source of Europe). What matters is the rivalry with (now mostly French) Latinity over the meaning of the historical sequence that is Europe's history.

Only it is not a duet. Geophilosophically speaking there is an invariable, if sometimes deliberately set aside or omitted, third hand in this drama of the modern geopolitical in the form of that most semidetached of European states: Britain (what Nietzsche, like most who do recall it, calls "England"). Always on the verge of another European Brexit of one kind or another, always ready to oppose itself to a "Continental Europe" that is itself (primarily) the divided German/French Europe, Britain too will have its say. I cited Mulhall's remarks on the sword-in-the-tree called "Nothung" a moment ago in part to help prepare get this into view: for he goes on to note that the British Arthurian legend embodied in the (not actually the) sword-in-the-stone called "Excalibur" represents a myth of 
British national identity "that is historically constructed (and repeatedly reconstructed) in opposition to the very aspects of Northern European culture... with which [Wagner] proposes to reconstruct German life and values" - and hence, we might now say, with which he proposes to reconstruct European life and values (Mulhall: 2013, p. 22). Britain has never been wholly cut off from (what it calls) the Continent, nor always - in fact, rarely - omitted in considerations of European life and values. It remains the case, however, that the philosophy of modern Europe has often exhibited a rather binary aspect: it is a French and German battle over who will be (or will have been) the "creator of a Europe" (Lacoue-Labarthe: 1990, p. 91).

Nietzsche is a notable exception here: his own experimental "synthesis" of the "European of the future" (Nietzsche: 1973, 170) is more or less entirely composed of a Germano-Franco-Britannic trio, although with a significant debt to Europe's Jews. However, with the exception of one (crucial) moment that we will come back to, this synthesis is constructed mostly by leaving everything "English" out.

I will examine Nietzsche's take (down) on the English at the end of this essay, but it is tempting to imagine an exemplary Britain in the "mimetic rivalry" we have been following here. Unlike Germany, Britain had been mostly Romanised. But there was a decisive break with Rome. And it came (not with a religious revolution but) with the demand of an English King not to be dictated to by an overweening and corrupt alien power: the Papacy. (He wanted a divorce.) One might wonder if the modern "English" model of liberty, or freedom as a political concept, has its own corresponding and commendable form: not as "sovereignty" (of "the people"), and not a fantasy of "autochthony" (of "the people") either but as "non-domination" (of whoever). With respect to the mimetic agon this would also imply a third way: that one can learn from the ancients - or indeed other moderns - but without thereby feeling oneself obliged to imitate them. Indeed.

When I come back to Nietzsche on the "English" I will also have something more to say about domination. As I indicated at the start, for Nietzsche the movement of political democratisation in Europe that unfolds from the French Revolution holds within its formation the possibility for the creation of a new European configuration beyond petty nationalisms: equality for all cannot finally be radically (or arbitrarily) restricted to "we French" or "we Germans" or "we English". As we have seen, Nietzsche sees the trajectory of this movement as the emergence of a new kind of "Man" whose identity is most radically marked by its national-self-overcoming: "good Europeans".

Such Europeans are not mono-cultural but in themselves distinctively multi-cultural and "supranational". Nations may seem to fade into the background here. However, in the construction of this new European humanity, Germany, the nation Nietzsche regards as the most stupidly nationalistic (because so promisingly European) of the silly European nations, remains, exemplary for the good Europeans to come:

The German soul is above all manifold, of diverse origins, more put together and superimposed than actually constructed: the reason for that is its source [viz] a large number of souls. As a people of the most tremendous mixture and mingling of races, with perhaps even a preponderance of pre-Aryan elements, a "people of the middle" in every sense, the Germans are more incomprehensible, more comprehensive, more full of contradictions...than other peoples are. (Nietzsche: 1973, p. 155)

As a "thinker who has the future of Europe on his conscience" (Nietzsche: 1973, p. 163) this "German" characteristic is central to Nietzsche's constructive task which is precisely a matter of 
selective-inheritance ("breeding") from the old European "stock". And while he takes Germany to be presently the main carrier of nationalist sickness - exemplary too, therefore, in its failure to be more boldly European, i.e. more boldly German ("Is this still German?") - he takes this multi-sourced German soul-characteristic as capable of giving rise to a built-in capacity for what he calls "development": its capacity to exist as a movement of becoming, and in the case under construction of becoming European, where that is precisely not being European (as such) at all, or being such only in the sense of being in a condition that has always belonged to Germany: of always holding open "the question" of what it is: of, always eluding "definition" (Nietzsche: 1973, p. 155). This is the first and most compelling "ruling concept" in his affirmation of what he calls the "Germanization of all Europe" (Nietzsche: 1973, p. 156). It would lie not in making Europeans more comprehensible, less comprehensive and less contradictory, but retaining those "German" characteristics as part of its new synthesis. Nevertheless, at issue for this multiplicity of souls is a Europe that, in the movement of democratisation, "wants to become one" (Nietzsche: 1973, p. 169)

Nietzsche sees here the possibility of Europe acquiring a new "single will": a supra-national European "single will" that would largely displace the "outmoded feelings" of national belonging (Nietzsche: 1973, p. 152). Nietzsche recognised that even "good Europeans" (himself, for example) would occasionally lapse into old and outmoded "atavistic attacks" of "fatherlandishness", but they would be short-lived and they would be quickly "restored" to their "good Europeanism" (Nietzsche: 1973, p. 152).

As I have indicated, Nietzsche's Europe of the future is not exclusively German - or, rather, it remains German through and through only because the German soul is already many. And, as I have stressed, Nietzsche does look beyond Germany in his "new synthesis" that constructs experimentally "the European of the future" (Nietzsche: 1973, p. 170). Those new European supra-nationals who have got over the stupid nationalism of Europe today, will most resemble, Nietzsche suggests, "such men as Napoleon, Goethe, Beethoven, Stendhal, Heirich Heine, Schopenhauer..., Richard Wagner..., writers from French late romanticism of the same period (especially Delacroix)" (Nietzsche: 1973, p. 170). A good mix of German and French figures there; vying for domination in the mimetic agon. Nietzsche will often refer to such individuals as "European events" rather than national ones (Nietzsche: 1973, p. 159). These are figures "like Goethe, like Hegel, like Heinrich Heine, [and] Schopenhauer" (Nietzsche: 1990, p. 79), all of whom avoided, for the most part, exclusive identification with a "fatherland" (Nietzsche: 1973, p. 170) - and in this case who were all German. Indeed, Nietzsche suggests that there is a greater chance of greatness that is due to the Germans than the French in view of the fact that "we... are still closer to barbarism than the French" (Nietzsche: 1973, p. 171).

The French get a pretty good run for their money nevertheless, and have "three claims" to superiority in spiritual culture over any other Europeans, and, Nietzsche stresses, they too "understand things that an Englishman will never understand" (Nietzsche: 1973, p. 168). For the most part, and once again, the agon over the future of Europe is a primarily French and German affair.

But the English will appear in Nietzsche's synthesis too - sort of. It is an unlikely event since no English figures figure as European events - or rather they only appear when what is at issue is, for example, the low point of European "feeling", the low point where "the same European destiny that in Beethoven knows how to sing found its way into words", and "into words" that Nietzsche clearly finds utterly unmusical: "Rousseau, Schiller, Shelley, Byron" (Nietzsche: 1973, p. 159; see also Nietzsche: 1973, p. 165). On the face of it, then, England is not a great contributor to this new 
Europe. The English are, Nietzsche thinks, "a race of former Puritans" (Nietzsche: 1973, p. 139) who are clever enough to make Sundays so "boring" that people look forward to going back to work on Monday (Nietzsche: 1973, p. 94). We (and I say "we" here deliberately) are "clumsy" and "ponderous", our literature is "impossible" (even Shakespeare takes a hit (Nietzsche: 1973, p. 134)), and our special vice is "cant" (i.e. whinging and whining - and he's right about that, especially about ourselves) (Nietzsche: 1973, p. 138-9). We cannot "dance", indeed Englishwomen, despite being "the most beautiful doves and swans" on earth can hardly "walk" (Nietzsche: 1973, p. 165). We are marked by our "profound averageness" (Nietzsche: 1973, p. 166), and the English utilitarians are "herd animals" who, preaching "one morality for all", are fundamentally detrimental to the "higher men". Indeed, the utilitarian's so-called "happiness of the greatest number" is anyway, in reality, simply the happiness of England. In short, the English contribution is absolutely minimal: "they are no philosophical race" ("it was against Hume that Kant rose up"), and "what is lacking in England" is "real power of spirituality" and "real depth of spiritual insight" (Nietzsche: 1973, pp. 164-5).

There is a certain exemplary representativity of everything awful about modern Europe...in the English. For Nietzsche the "profound averageness" of the English is precisely what "the German spirit has risen against in profound disgust" (Nietzsche: 1973, p. 97). And as we have seen, what should be preserved from the German spirit is best understood as, precisely, its potential for becoming the leading spirit of the new "good European".

\section{V}

But wait! While it seems to Nietzsche that no Englishman has ever been a "European event", he seems also to think, amazingly, that, nevertheless, it would be "useful for such [English] spirits to dominate for a while" (Nietzsche: 1973, p. 165). Ha! What a turn up for the books, especially when a Brexit pattern is already in view. I will exploit this.

Nietzsche's reasons for giving the English a temporary priority in dominating the movement towards the new Europe are basically practical and pragmatic: working towards a new Europeanism will be safer in the hands of "mediocre spirits" instead of the "exalted spirits" of the French and German type who have a tendency to "fly off", not keeping to the "rules" (Nietzsche: 1973, pp. 165-6). English "narrowness, aridity and industriousness" is thus better suited to "dominate" in our time "for a while", even though we are utterly incapable of "being able...to be something new" (Nietzsche: 1973, p. 166).

Well, thank you. But having been given the floor by Nietzsche (for now), I would like to suggest immediately and in closing that what Europe needs today, tomorrow and any day thereafter, really is not the "German" ideal of unity through (anyone's) domination. Let's call that the German interpretation of "ever closer union": the one that conceives it on a becoming-increasingly-morefederalist model, a model in which the nations of Europe become merely "implementing authorities" of a European supra-national government (Habermas). Instead, I would urge a (genuinely) more modest proposal: where "ever closer union" simply means cultivating conditions in which war between the nations of Europe becomes increasingly less likely. We Europeans (since you don't mind an Englishman speaking in this name) are, I think, a unity only of the singularly different: we can be drawn together as one (spiritually) precisely because we are not one (spirit). We are the one that is not one.

We Europeans, we are in trouble again now, in our today. Not simply because of some "purely external" threat from outside us, but in a paralyzing uncertainty regarding the kind of unity we want to make of ourselves. In this essay I have focused on one troubling thing that a perhaps still recognizably "German" spirit within us is now increasingly desiring for ourselves: the unity of a 
"single will". The "English" spirit in Europe (even if no longer in the EU) simply holds fast to Nietzsche's acknowledgment of "manifold souls". What made us a "we" really worthy of the name what made it worth speaking about "we, the Europeans" all together as one and all distinctively European - is, as J.S. Mill put it, our "individuality": the "singularity" of the people and peoples within the diverse nations of Europe, and their "unlikeness" one to another (Mill: 2015, p. 66). And there we "English" spirits want to stick. Yet today, Mill says - Mill in his today which is very close to Nietzsche's and also not so very far from our own - today this modest union is weakened by forces which imagine it would be strengthened by a more radically assimilating, amalgamating "we":

What has hitherto preserved Europe from [becoming stationary]? Not any superior excellence in the [European family], which, when it exists, exists as the effect not as the cause; but their remarkable diversity of character and culture. Individuals, classes, nations, have been extremely unlike each other: they have struck out a great variety of paths, each leading to something valuable; and although at every period those who travelled in different paths have been extremely intolerant of one another, and each would have thought it an excellent thing if all the rest could have been compelled to travel his road, their attempts to thwart each other's development have rarely had any permanent success, and each has in time endured to receive the good which the others have offered. Europe is, in my judgement, wholly indebted to this plurality of paths for its progressive and many-sided development. (Mill: 2015, p. 67)

While Mill does not explore the idea directly, the creation of a European Union that wants both to preserve and secure the diversity of Europe's nation states and to reduce their extreme intolerance of one another is surely something he would welcome. So his text offers a timely warning for the present generation of European enthusiasts: that its courageous efforts to achieve "ever closer union between the peoples [sic] of Europe" carries inside itself the threat of wanting the plurality invoked here finally to be eliminated as a politically salient feature of Europe's politics - a final overcoming of what Habermas sees as the debilitating effects of "national particularisms" in European politics - as if the ideal telos of European integration would be the creation of a "European people" that really is one because it really is one.

In Mill's view, by contrast, and I think we still need to heed this, the best and most European of Europeans today are those who come to "see that it is good that there should be differences" (Mill: 2015, p. 68). The alternative is a nightmare of a distinctively European form of history-ending "stationariness": the levelling demand for uniformity that, often enough in the form of a profoundly hollowed-out appeal to "democratic feeling", betrays Europe because it "proscribes singularity" (Mill 2015, p. 66). For sure, what we need, what many of us singularly will, is indeed a united Europe of states. But this is not a call for an international state or "supranational democracy", but, rather, for a transformation of the fractious nation states of Europe into co-operative member states of their union, a union that would not itself having the dominating power like that of a state. In the referendum the majority of UK citizens who voted said "No" to what they were increasingly framing as a project of supranational power, preferring what looks like non-domination to a promise of economic stability that many were not seeing anyway.

\section{Bibliography}

Habermas, Jürgen. "Democracy, Solidarity and The European Crisis", https://www.socialeurope.eu/2013/05/democracy-solidarity-and-the-european-crisis/

Heidegger, Martin. What is Philosophy? Lanham: Rowman \& Littlefield, 1956.

Lacoue-Labarthe, Phillipe. Heidegger and the Politics of Poetry. Illinois: University of Illinois Press, 2007.

------ Heidegger, Art and Politics, Oxford: Blackwell, 1990. 
Mill, J.S. On Liberty, Utilitarianism and Other Essays. Oxford: OUP, 2015.

Mulhall, Stephen. The Self and its Shadows, Oxford: OUP, 2013.

Nietzsche, Friedrich. Beyond Good and Evil. Harmondsworth: Penguin Classics, 1973.

------ Twilight of the Idols. Harmondsworth: Penguin Classics, 1990. 